\title{
Analysis of the Effects of Bone Marrow Biopsy Decalcification Methods on Histopathological Examination
}

\author{
Ji Young Park, Kyung Hee Han \\ Department of Pathology, Yonsei University Severance Hospital, Seoul 03722, Korea
}

\section{골수생검조직의 조직병리검사에서 탈회방법에 따른 결과 분석}

박지영, 한경희

연세대학교 세브란스병원 병리과

\begin{abstract}
Decalcification is routinely performed to obtain a pathological diagnosis using bone marrow biopsy. During the decalcification process using a conventional acidic solution, such as $\mathrm{HCl}$, the antigenicity of tissue is damaged. Especially DNA and RNA in the bone marrow are impaired. Hence, there is the need for a standardized decalcification protocol that preserves the antigenicity of tissue. To this end, we compared the effects of two commonly used decalcifiers: Commercial decalcifier (Calcl-Clear Rapid, $\mathrm{HCl}$ ) and the EDTA (12.5\%, pH 7.0). Bone marrow biopsies sampled from 71 patients were decalcified in accordance with the protocols of respective groups- $\mathrm{HCl}$ versus EDTA. The differences of decalcification protocols were analyzed with respect to Hematoxylin \& Eosin staining, Gomori'sreticulum staining, and immunohistochemical staining and molecular analysis. Immunohistochemical staining used $\mathrm{Ki}-67$, CD20 and CD138 as primary antibodies and molecular analysis was conducted through the DNA concentration analysis, in situ hybridization (ISH) and immunoglobulin heavy chain (IGH) gene rearrangement. On the routine histopathology analysis, there was no difference between $\mathrm{HCl}$ and EDTA. Moreover, in case of immunohistochemical staining, the cytoplasmic membrane or cytoplasmic CD markers was well preserved. However, nuclear proteins, such as Ki-67, were stained with low quality. Conversely, according to the molecular analysis, the EDTA protocol preserved the DNA and RNA compared with the $\mathrm{HCl}$. The differences of DNA quantity and quality were statistically significant between protocols of $\mathrm{HCl}$ and EDTA. We used 38 cases in $\mathrm{HCl}$ and 12 cases in EDTA. Consequently, the EDTA protocol maintains the antigenicity of the protein on tissue and is acceptable for examination with molecular base analysis. Decalcification of bone marrow biopsy by EDTA is highly recommended for the examination of immunohistochemical staining and molecular analysis.
\end{abstract}

Key words: Bone marrow biopsy, Decalcification, $\mathrm{HCl}$, EDTA

This is an Open Access article distributed under the terms of the Creative Commons Attribution Non-Commercial License (http://creativecommons.org/licenses/by-nc/4.0) which permits unrestricted non-commercial use, distribution, and reproduction in any medium, provided the original work is properly cited.

Copyright $\odot 2016$ The Korean Society for Clinical Laboratory Science. All rights reserved.
Corresponding author: Kyung Hee Han Department of Pathology, Yonsei University Severance Hospital, 50-1 Yonsei-ro, Seodaemun-gu, Seoul 03722, Korea Tel: 82-2-2228-2631 Fax: 82-2-2227-7939

E-mail: hankh9121@yuhs.ac

Received: September 5, 2016 Revised $1^{\text {st: }}$ September 30, 2016 Revised $2^{\text {nd }}$ : October 5, 2016 Revised 3 ${ }^{\text {rd: }}$ : October 5, 2016 Revised $4^{\text {th }}$ : October 5, 2016 Accepted: October 5, 2016

\section{서 론}

골수는 뼈의 내부를 구성하는 성분으로 조혈작용을 통해 인체의 면역을 담당하는 적혈구 및 백혈구를 생성하는 조직이다. 환자로부
터의 골수천자를 시행하는 것은 다발성골수종과 같은 악성종양이 나재생불량성빈혈증 혹은 결핵과 같은 감염병을 진단하기 위하여 이루어진다. 이렇게 채취된 골수생검조직은 병리학적 진단을 위하 여 일반적으로 $10 \%$ 중성 완충 포르말린용액에 고정을 거친 후 골수 
조직에 포함된 칼슘을 제거하는 탈회과정을 거친다. 이때 탈회과정 에 사용되는 용액은 성분에 따라 크게 3 가지로 나뉜다. 첫째, $\mathrm{HCl}$ 과 nitric acid 같은 강산을 희석해서 사용하는 것으로 탈회속도가 빠 르다는 장점 때문에 폭넓게 사용되고 있으며, 기존에 상품화된 제 품들이 강산을 주요성분으로 만들어져 있다. 그러나 조직내의 DNA나 RNA에 손상을 가해 면역조직화학염색이나 분자병리검사 에 영향을 미치는 것으로 보고되어 있다[1]. 둘째, formic acid와같 은 약산을 희석하여 사용하는 것으로 $\mathrm{HCl}$ 보다는 탈회속도가 느리 고 세포에 손상을 적게 준다고 알려져 있으나, formic acid에 의한 탈회과정 시 DNA가 손상된다고 보고되었다[2]. 셋째, ethylenediaminetetraacetic acid (EDTA)와 같은 chelating agent로써 검 체 내에 칼슘이온과 천천히 반응하여 세포 내 손상을 최소화하며 조직 내에 단백질 및 DNA와 RNA를 안정적으로 잘 보존하여 면역 및 분자검사에 적합하다고 알려져 있다[3,4]. 이에 본 연구는 세브 란스병원에 내원한 환자의 골수생검조직을 크게 두 그룹으로 나누 어 각각 $\mathrm{HCl}$ 과 $\mathrm{EDTA}$ 가 포함된 탈회용액으로 처리한 후 일반적인 조직병리학적검사, 면역병리학적검사, 분자병리학적검사 결과에 어떤 영향을 미치는지 알아보기 위해 실험을 진행하였다. 정성적으 로는 골수생검조직의 일반염색과 특수염색 및 면역조직화학염색 을 시행하여 두 가지 탈회방법에 따른 결과를 비교하여 EDTA 탈회 가 우수한 가를 검증하였다. 또한 골수조직으로부터 DNA를 추출 하여 $\mathrm{EDTA}$ 로 탈회한 골수조직이 $\mathrm{HCl}$ 로 탈회한 골수조직에 비해 $\mathrm{DNA}$ 농도가 유의하게 높은 가를 정량적으로 분석하였고, 동시에 추출한 DNA로 IGH gene rearrangement 검사를 시행하여 EDTA 탈회가 분자병리검사에도 적합한 가를 확인하였다.

\section{재료 및 방법}

\section{1. 연구재료}

세브란스병원에서 2014년도에 골수천자가 시행된 38 예의 골 수생검조직과 2015년도에 골수천자가 시행된 33 예의 골수생검 조직을 연구재료로 사용하였다. 본 실험에 사용된 검체는 연세의료 원 세브란스병원 연구심의위원회의 승인을 받아 시행하였다(승인 번호: YUHS, SH 4-2016-0399).

Table 1. The decalcification methods

\begin{tabular}{lcc}
\hline Decalcifying agent & Processing time & $\begin{array}{c}\text { Processing } \\
\text { temperature }\end{array}$ \\
\hline HCl (Calci-Clear Rapid) & $8 \mathrm{hr}$ & Room temperature \\
EDTA (12.5\%, pH7.0) & $24 \mathrm{hr}$ & Room temperature \\
\hline
\end{tabular}

Abbreviation: $\mathrm{HCl}$, hydrochloric acid; EDTA, ethylenediaminetetraacetic acid disodium salt dehydrate.

\section{2. 조직병리학적 검사}

골수천자가 시행된 골수생검조직을 $10 \%$ 중성포르말린용액 (neutral buffered formalin, NBF)에 24시간 고정한 후 크게 두 그 룹으로 나누어 $\mathrm{HCl}$ 탈회용액에 8시간, EDTA 탈회용액에 24시간 을 각각 탈회시켜 파라핀 블록을 만든 후 조직슬라이드 표본을 제 작하였다. 상용 $\mathrm{HCl}$ 탈회용액은 Calci-Clear Rapid (National Diagnostics, Atlanta, USA)을 사용하였으며, EDTA 탈회용액은 EDTA (Sigma, St. Louis, USA)와 NaOH (Sigma, Staint Louis, $\mathrm{USA}$ )를 이용하여 $12.5 \%$ (pH7.0) 농도로 제조하여 사용하였다. $\mathrm{EDTA}$ 탈회용액의 $\mathrm{pH}$ 는 최근 간행물을 참조하여 제조하였다[3,5]. 파라핀블록은 $3 \mu \mathrm{m}$ 로 박절하여 절편을 제작하였으며 조직병리학 적 진단을 위해 시행하는 hematoxylin \& eosin 염색과 골수 조직 내에 세망섬유의 변화를 확인하기 위해 Reticulum II 염색키트 (Ventana, Tucson, USA)를 이용하여 Bench Mark XT 자동염색기 (Ventana, Tucson, USA)로 reticulum 염색을 시행하였다(Table 1).

\section{3. 면역조직화학적 검사}

골수생검조직의 탈회과정에서 사용된 용액에 따른 면역조직화 학적 검사결과의 차이를 분석하기 위해 BenchMark XT 자동염색 기(Ventana) 장비를 사용하였다. 면역조직화학염색 시 내인성 과 산화효소를 차단하기 위하여 $3 \% \mathrm{H}_{2} \mathrm{O}_{2}$ 를 10 분간 처리하였으며, 항 원부활방법으로는 tris based buffer를 주 성분으로 $\mathrm{pH} 8.4$ 로 하는 $\mathrm{CC1}$ (Ventana)용액을 사용하여 30분간 반응시켰다. 1차항체로 핵 내 단백질인 $\mathrm{Ki}-67$ 과 세포질 및 세포막 단백질인 CD20과 $\mathrm{CD} 138$ 을 사용하여 실온에서 1시간 반응시킨 후 Ultra View Universal DAB Detection 키트(Ventana)를 이용하여 발색하였다 (Table 2).

\section{4. 분자병리학적 검사}

골수생검조직의 탈회과정에서 사용된 용액에 따른 분자병리학 적 검사결과의 차이를 각 검사 별로 시행하여 분석하였다. 우선, in situ hybridization (ISH)검사를 시행하였다. 다발성 골수종의 정 확한 병리학적 진단을 위해 kappa와 lambda의 immunoglobulin (Ig) light chain에 대한 ISH 검사를 시행하였다[6]. Kappa와 lambda light chain의 발현양을 검출하기 위하여 mRNA probe

Table 2. Primary antibodies for immunohistochemical staining

\begin{tabular}{ccccc}
\hline Antibody & Dilution & Clonality & Clone & Company \\
\hline Ki-67 & $1: 150$ & Monoclonal & MIB-1 & Dako \\
CD138 & $1: 400$ & Monoclonal & M115 & Dako \\
CD20 & $1: 10$ & Monoclonal & L26 & Dako \\
\hline
\end{tabular}


(Ventana)를 사용하였으며 Bench Mark XT 자동염색기(Ventana) 장비로 시행하였다. 그 다음, 환자로부터 채취된 골수생검조직 중 $\mathrm{HCl}$ 용액으로 탈회과정을 거친 38 예와 EDTA 용액으로 탈회과정 을 거친 12 예에 대하여 $\mathrm{DNA}$ 를 추출한 후 농도를 측정하였다. Maxwell CSD DNA FFPE 키트와 Maxwell 16 핵산추출기 (Promega, Madison, USA)를 사용하여 DNA를 추출하였으며, Nanodrop 2000 spectrophotometer (Thermo, Waltham, USA) 로 $\mathrm{DNA}$ 의 농도를 측정하였다. 마지막으로 추출된 $\mathrm{DNA}$ 를 이용하 여 다발성골수종의 확진에 필요한 B-cell의 IGH gene rearrangement 검사를 Identiclone IGH gene clonality assay 키트 (Invivoscribe, San Diego, USA)를 사용하여 시행하였다.

\section{5. 통계처리}

$\mathrm{DNA}$ 의 추출 후 농도와 유의성 평가를 SPSS 버전 21 통계 프로 그램(IBM, Armonk, NY USA)을 이용하여 평균치와 표준오차를 계산하였으며, 결과해석의 유의 수준은 $p<0.05$ 로 시행하였다.

\section{결 과}

\section{1. $\mathrm{HCl}$ 과 EDTA 탈회용액에 처리 후 조직학적 검사결과의 차이}

두 종류의 탈회용액에 따른 핵과 세포질의 조직학적 차이는 hematoxylin \& eosin 염색을 통해 관찰하였다. HCl과 EDTA 탈회 용액에 따른 세포나 조직염색의 차이는 없었으며 조직학적 특징들 을 잘 관찰할 수 있었다. 또한 골수생검조직에서 hematoxylin \& eosin 염색과 더불어 통상적으로 염색하는 Gomori's reticulum
염색을 시행하였다. 골수 조직 내 세망섬유의 경우 발현양에 따라 0 4까지 등급을 정해 보조적인 진단으로 사용하였다. 그 결과 hematoxylin \& eosin 염색상과 마찬가지로 탈회용액에 따른 발현 양의 차이는 발견되지 않았다(Fig. 1).

\section{2. $\mathrm{HCl}$ 과 EDTA 탈회용액에 처리 후 면역조직화학적 검사결과의 차이}

세포증식 표지자로써 핵 내 단백질인 Ki-67의 경우에는 두 탈회 용액에 따른 염색상의 차이가 발견되었다. 골수생검조직을 $\mathrm{HCl}$ 탈 회용액에 처리한 경우 36 예의 골수조직 중 20 예에서 뚜렷한 염색 상을 얻은 반면, $\mathrm{EDTA}$ 탈회용액에 처리한 경우 33 예의 골수 조직 중 32 예에서 우수한 염색결과를 얻었다. 이 때 EDTA 탈회용액 처 리 후 Ki-67에 염색되지 않은 1 예 슬라이드를 관찰한 결과 조직내 의 세포성분의 부족에 기인한 것으로 판단되었다. 그 다음 실험은 B-cell 전구세포나 성숙한 B-cell의 세포질 또는 세포막에서 발현 하는 CD20과 B-cell 분화 마지막 단계에 발현하는 CD138의 면역 조직화학염색을 시행하였고 그 결과 $\mathrm{HCl}$ 과 EDTA 탈회용액에 따 른 염색결과의 차이를 발견할 수 없었다. $\mathrm{CD} 20$ 의 경우 $\mathrm{HCl}$ 탈회용 액에 처리한 경우 5 예의 골수조직 중 4 예의 양성 염색상이 관찰되 었고, $\mathrm{EDTA}$ 탈회용액에 처리한 경우 4 예의 골수생검조직 중 4 예 모두 양성 염색상이 관찰되었다. $\mathrm{HCl}$ 탈회용액에 처리 후 $\mathrm{CD} 20$ 에 염색되지 않은 1 예의 경우에는 골수 내 모든 세포가 형질세포로의 세포분화가 완료되었음을 $\mathrm{CD} 138$ 추가 면역조직화학염색으로 확 인할 수 있었다. 또한 $\mathrm{CD} 138$ 의 경우에는 $\mathrm{HCl}$ 탈회용액에 처리 후 염색을 시행한 9 예 모두에서 양성 염색상이 관찰되었고, $\mathrm{EDTA}$ 탈

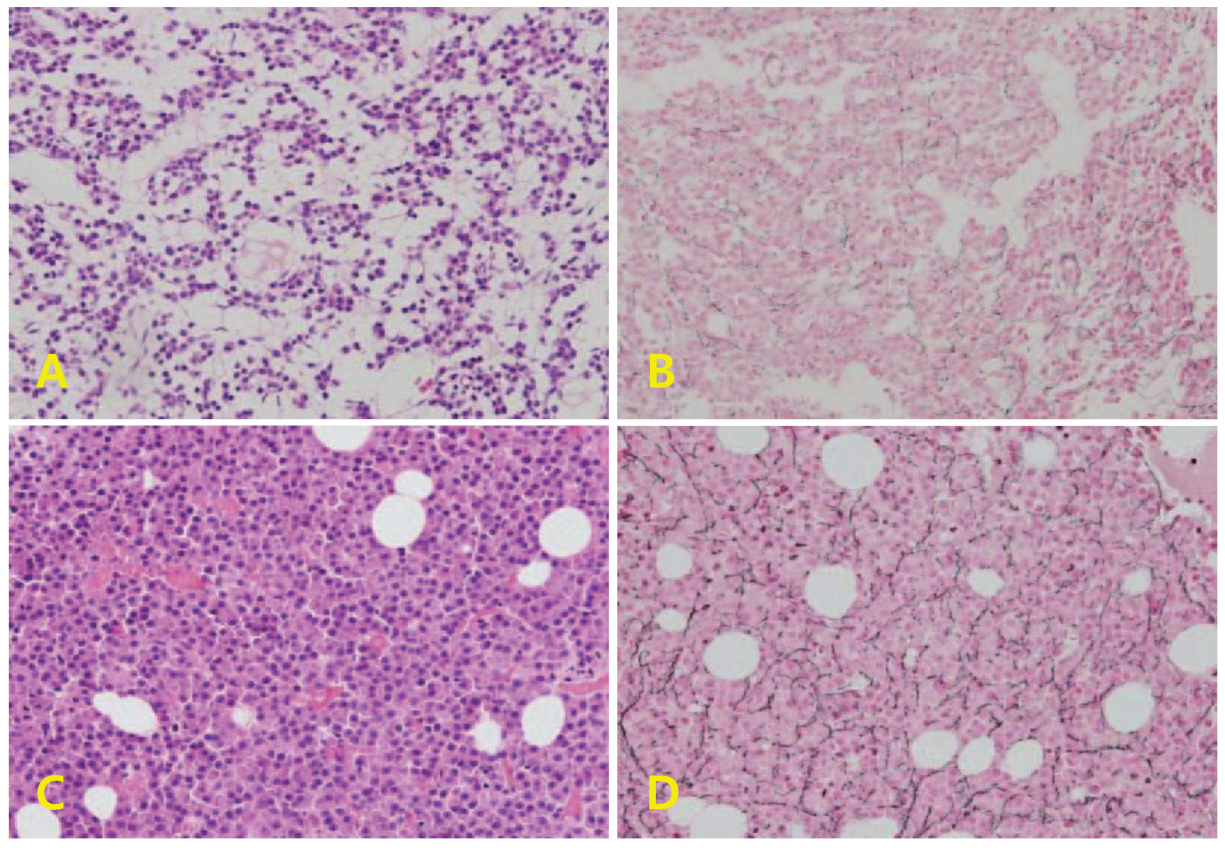

Fig. 1. The results of $\mathrm{H} \& \mathrm{E}$ and Reticulum stain according to decalcification methods $(\times 200)$. The results of hematoxylin \& eosin stain (A) and reticulum stain (B) after $\mathrm{HCl}$ decalcification. The results of hematoxylin \& eosin stain (C) and reticulum stain (D) after EDTA decalcification. 
회용액에 처리한 후 염색을 시행한 16 예 모두에서도 뚜렷한 양성 염색상이 관찰되었다(Table 3, Fig. 2).

\section{3. $\mathrm{HCl}$ 과 EDTA 탈회용액에 처리 후 분자병리학적 검사결과}

1) In situ hybridization (ISH)

ISH 검사는 골수생검조직 내에서 발현되는 RNA양을 확인하기 위한 검사법으로 이미 다발성골수종으로 진단된 환자의 골수생검 조직을 연구재료로 사용하여 kappa와 lambda light chain의 과발 현 여부를 알아보았다. ISH 시행 전 면역조직화학염색을 통해 $\mathrm{HCl}$ 탈회용액으로 처리한 골수생검조직과 EDTA 탈회용액으로 처리한 골수생검조직 모두 kappa light chain-restriction이 발현됨을 확 인한 후 동일한 골수생검조직에서 $\mathrm{ISH}$ 검사를 시행하였다. $\mathrm{HCl}$ 탈 회용액으로 처리한 경우에는 kappa와 lambda light chain의 ISH 검사에서 적절한 검사 결과를 얻을 수 없었으나 EDTA 탈회용액으

Table 3. The results of immnohistochemical staining according to decalcification methods

\begin{tabular}{ccc}
\hline Antibody & $\mathrm{HCl}^{*}$ & EDTA $^{*}$ \\
\hline Ki-67 & $20 / 36$ & $32 / 33$ \\
CD20 & $4 / 5$ & $4 / 4$ \\
CD138 & $9 / 9$ & $16 / 16$ \\
\hline
\end{tabular}

*Positive case/total tested case.
로 처리한 경우에는 면역조직화학염색에서의 결과와 동일한 kappa light chain-restriction을 확인할 수 있었다(Fig. 3).

\section{2) DNA의 추출 및 농도측정}

환자로부터 채취된 골수생검조직 중 $\mathrm{HCl}$ 탈회용액에 처리한 38 예와 EDTA 탈회용액에 처리한 12 예에 대하여 DNA를 추출한 후 순도 및 농도를 측정하였다. 순도의 측정은 spectrophotometer의 $\mathrm{A}_{260} / 280 \mathrm{~nm}$ 의 비율로 확인할 수 있으며 $\mathrm{HCl}$ 탈회용액에 처리한 38 예의 경우 $1.64 \pm 0.33, \mathrm{EDTA}$ 탈회용액에 처리한 12 예의 경우 $1.88 \pm 0.04$ 로 $\mathrm{DNA}$ 의 순도가 측정되었다. $\mathrm{DNA}$ 농도의 경우에도 $\mathrm{HCl}$ 과 EDTA 탈회용액에 처리한 골수생검조직은 각각 $16.5 \pm 19.3$, $32.6 \pm 15.4$ 로 측정되었으며, EDTA 탈회용액에 처리한 검체가 $\mathrm{HCl}$ 탈회용액에서 보다 두 배 이상 $\mathrm{DNA}$ 의 농도가 높음을 확인 할 수 있었다(Table 4, Fig. 4).

\section{3) IGH 유전자 재배열검사를 시행하여 추출된 DNA의 질 평가}

$\mathrm{B}-\mathrm{cell}$ 에서 유래된 질환 중 악성여부를 감별하기 위한 분자병리 검사법으로 multiplex PCR법에 기반을 둔 IdentiClone IGH clonality assay를 시행하였다. 이때, 검사에 사용된 DNA의 순도 와 농도가 우수할 때 정확한 결과를 얻어낼 수 있다. $\mathrm{HCl}$ 탈회용액 에 처리된 임의 검체 $\mathrm{A}, \mathrm{B}$ 와 EDTA 탈회용액에 처리된 임의의 검체 $\mathrm{C}, \mathrm{D}$ 를 사용하여 진행하였다. $\mathrm{A}$ 와 $\mathrm{B}$ 검체의 농도와 순도는 각각

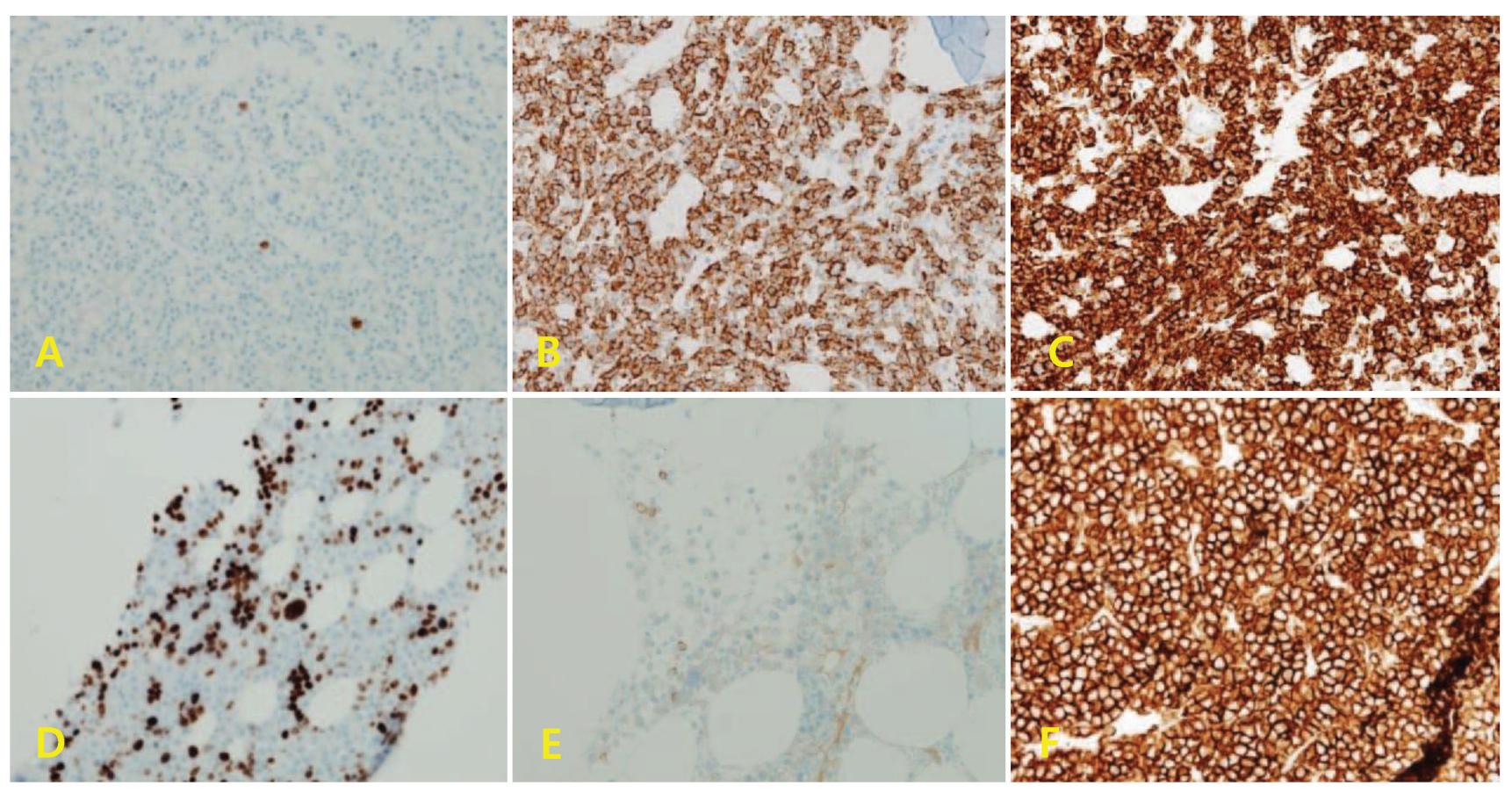

Fig. 2. The results of immunohistochemical stain according to decalcification methods ( $\times 200)$. The results of Ki-67 (A), CD20 (B), CD138 (C) after $\mathrm{HCl}$ decalcification. The results of Ki-67 (D), CD20 (E), CD138 (F) after EDTA decalcification. 

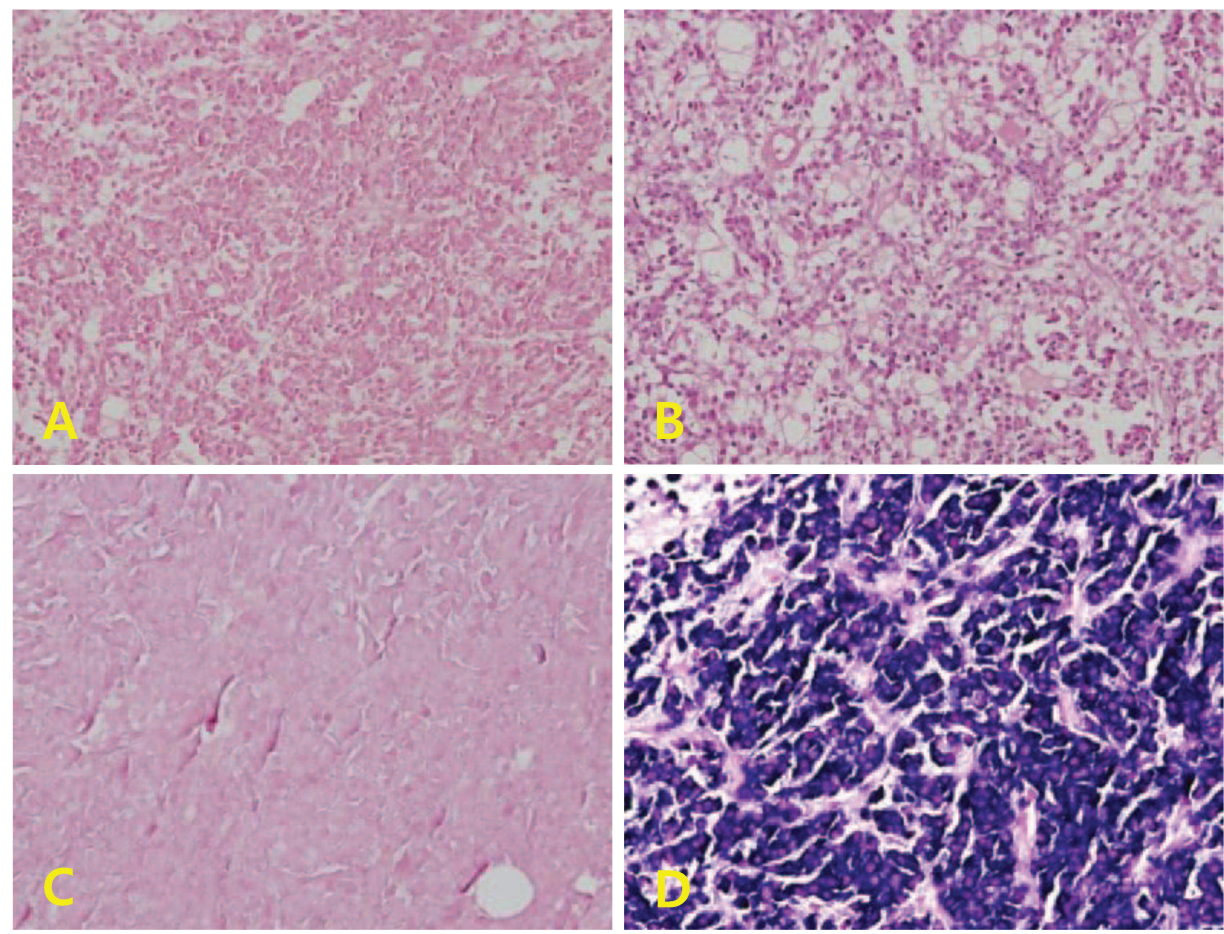

Fig. 3. The results of in situ hybridization (ISH) according to decalcification methods $(\mathrm{x} 200)$. The results of kappa ISH (A) and lambda ISH (B) after $\mathrm{HCl}$ decalcification. The results of kappa ISH (C) and lambda ISH (D) after EDTA decalcification.
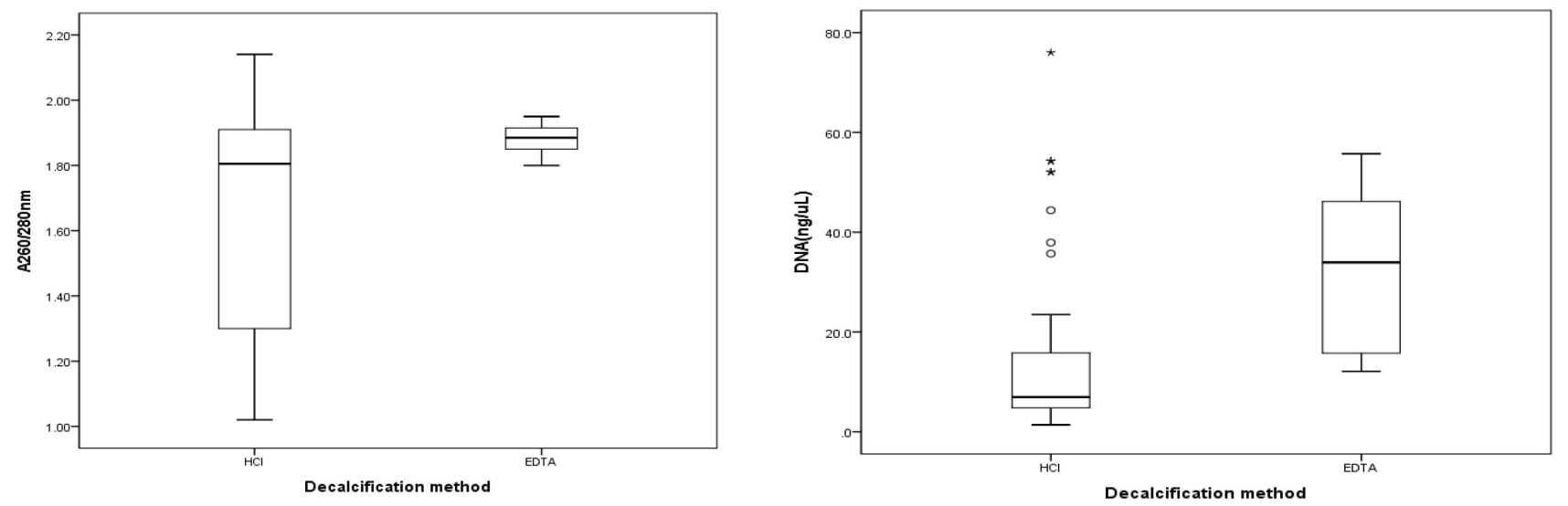

Fig. 4. Quality and quantity of DNA according to decalcification methods.

$76.0 \mathrm{ng} / \mu \mathrm{L}, 1.80,5.2 \mathrm{ng} / \mu \mathrm{L}, 1.02$ 측정되었고, C와 D 검체의 농도 와순도는 각각 $36.7 \mathrm{ng} / \mu \mathrm{L}, 1.84,55.7 \mathrm{ng} / \mu \mathrm{L}, 1.85$ 로 측정되었다. IdentiClone IGH clonality assay에 사용된 primer는 5종류로 V-J영역의 conserved framework (FR1-JH, FR2-JH) 및 joining regions (FR3-JH)과 diversity (DH-JH) 및 joining regions (DH7-JH)을 사용하였다. $\mathrm{HCl}$ 탈회용액에 처리한 $\mathrm{A}$ 검체는 순도와 농도가 우수한 것으로 선택하였고, B 검체는 순도와 농도가 매우 낮 은 것으로 선택하였다. 이에 A 검체는 IGH gene rearrangement 검사 결과 악성질환 여부를 감별할 수 있었으나, $\mathrm{B}$ 검체는 어떤 결 과도 전혀 얻을 수 없었다. 반면 $\mathrm{EDTA}$ 탈회용액을 처리한 C, D 검
체는 모두 IGH gene rearrangement 검사에서 악성질환 여부를 감별 할 수 있는 결과를 얻었다(Fig. 5).

\section{고 찰}

최근에는 환자에서 채취된 골수생검조직의 최종적인 진단과 치 료를 위해 분자기법에 기인한 병리검사를 많이 시행하고 있다. 이 에 골수생검조직의 탈회 과정은 최종적인 병리진단 결과에 영향을 줄수 있는 만큼 중요한 단계로 여겨진다[7]. 기존에 짧은 탈회시간 과 저렴한 비용으로 인해 많이 사용되던 $\mathrm{HCl}$ 탈회용액에 의한 탈회 


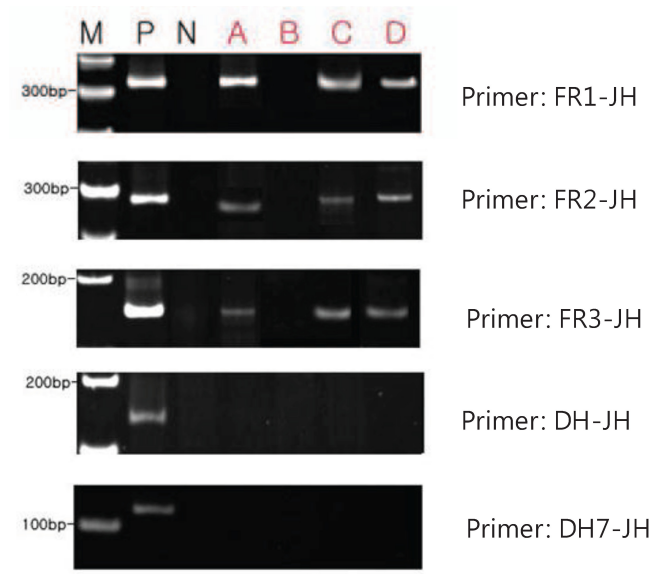

Fig. 5. The results of immunoglobulin heavy chain gene rearrangement $(\mathrm{IGH})$. The sample $\mathrm{A}$ and $\mathrm{B}$ after $\mathrm{HCl}$ decalcification vs sample $C$ and $D$ after EDTA decalcification are compared by IGH. Abbreviation: $M$, size marker; $P$, positive control; $N$, negative control; A D, sample.

과정은 이미 많은 논문을 통해 조직내의 DNA와 RNA를 손상시키 고, 단백질을 변성시킨다고 보고되어 있다[8]. 또한 최근 논문에서 는 EDTA 탈회용액에 의한 탈회과정이 골수조직의 다양한 병리검 사 결과에 우수하다고 알려져 있으며, 특히 real-time PCR과 in situ hybridization과 같은 유전학적 검사에서 탁월한 검사결과를 보여준다고 발표되었다[5].

본 논문에서는 세브란스병원에 내원한 환자의 골수생검조직을 연구재료로 하여 $\mathrm{HCl}$ 과 EDTA 탈회용액에 의한 탈회과정에 따라 병리검사결과의 차이를 일반염색, 특수염색, 면역조직화학염색 및 분자병리검사를 시행하여 분석하였다. $\mathrm{HCl}$ 탈회용액으로 처리한 경우, 형태학적 변화를 확인하기 위한 hematoxylin \& eosin 염색 에서 핵과 세포질이 뚜렷하게 염색되어 병리학적 변화양상을 관찰 할 수 있었고, 세망섬유의 변화를 관찰하기 위한 reticulum 염색 또 한 뚜렷하게 염색되었다. 반면 면역조직화학염색의 경우에는 표적 항원의 발현위치에 따라 염색결과에 차이를 보였다. Ki-67과 같이 핵 내에서 발현하는 항원의 경우 일부 검체에서 염색결과를 얻을 수 없었다. 그러나 세포증식 표지자의 경우에는 세포막 혹은 세포 질에서 발현하는 단백질로 $\mathrm{HCl}$ 탈회용액에 의한 염색결과의 영향 은 받지 않아 양호한 염색결과를 얻을 수 있었다. 이러한 항체발현 위치에 따른 면역조직화학염색 결과를 토대로 $\mathrm{HCl}$ 탈회용액이 핵 내 성분의 염색결과에만 영향을 미치고 있음을 알 수 있었다. 구체 적으로 $\mathrm{HCl}$ 탈회용액의 핵 내 영향을 알아보기 위하여 다발성골수 종의 대표적인 진단방법인 kappa와 lambda ISH 검사를 시행하였 고, 그 결과 표적 RNA가 파괴되어 염색상태가 불량하였다. 이를 토 대로 $\mathrm{HCl}$ 탈회용액이 조직 내 RNA를 손상 입혔음을 추론할 수 있 었다. 또한 DNA 손상여부 확인을 위한 DNA 추출 및 IGH gene
Table 4. Quantity and quality of DNA according to decalcification methods

\begin{tabular}{|c|c|c|c|}
\hline & $\mathrm{HCl}$ & EDTA & $p$-value \\
\hline $\mathrm{A}_{260} / \mathrm{A}_{280 \mathrm{~nm}}$ & $1.64 \pm 0.33$ & $1.88 \pm 0.04$ & $<0.000$ \\
\hline DNA yield (ng/ $\mu \mathrm{L})$ & $16.5 \pm 19.3$ & $32.6 \pm 15.4$ & $<0.007$ \\
\hline
\end{tabular}

rearrangement 검사에서도 면역조직화학염색 결과와 동일하게 Ki-67 염색결과가 불량한 검체의 경우 추출된 DNA의 농도가 매우 낮았으며, IGH 검사결과도 전혀 얻을 수 없었다. IGH 검사는 다발 성골수종의 단클론성을 확인하기 위한 것으로, 중합효소연쇄반응 을 한 후 전기영동 결과를 바탕으로 모든 primer중 한 개의 primer 에서라도 양성 대조군과 같은 단일 밴드가 나타날 때 B-cell의 단클 론성 증식이 있는 것으로 확인한 후 종양성 질환으로 판독한다[9]. 일반적으로 종양성 질환일 경우 FR1-JH, FR2-JH, FR3-JH primer 에서 종종 단일밴드가 나타난다. 그러나 $\mathrm{HCl}$ 탈회용액으로 처리 후 $\mathrm{DNA}$ 를 추출하여 그 순도와 농도를 측정한 결과 모든 골수 조직이 손상된 것은 아닌 것으로 확인할 수 있었다. EDTA 탈회용액으로 처 리한 경우에는, $\mathrm{HCl}$ 탈회용액보다 긴 반응시간을 필요로 하며, 조 직의 크기에 따른 반응속도에도 민감한 단점이 있다[10]. 그러나 면 역조직화학염색 결과는 $\mathrm{HCl}$ 탈회용액에 탈회 시 불량한 염색소견 을 보였던 Ki-67과 같은 핵 내 항원뿐 아니라 CD20 혹은 CD138같 은 세포질, 세포막을 표적항원으로 하는 모든 항체에서 잘 염색되 었다. 또한 추출된 DNA는 높은 농도와 순도를 나타내어 IGH gene rearrangement 검사를 시행함에 있어서 정확한 분자병리검사 결 과를 얻을 수 있었다[11]. 이 연구를 통해서 EDTA 탈회방법이 골수 생검조직을 이용한 병리검사에서 $\mathrm{HCl}$ 탈회방법에 비해 우수하다 는 것을 다시 한 번 입증할 수 있었다. 특히 EDTA 탈회방법이 면역 병리검사 및 분자병리검사 결과의 질을 향상시켜 병리과에서 환자 의 질병을 정확히 진단하는데 기여할 것으로 판단된다.

\section{요 약}

탈회방법은 골수조직의 병리학적 진단을 위해서 항상 시행되는 과정이다. $\mathrm{HCl}$ 탈회용액과 같이 주로 사용하고 있는 산성용액은 탈 회과정 동안에 조직내의 항원성에 손상을 입힌다. 특히, 골수조직 내의 RNA나 DNA에 심하게 손상을 준다. 따라서 조직의 항원성을 보존하기 위한 표준화된 탈회방법이 필요하다. 본 연구는 일반적으 로 가장 많이 사용되는 $\mathrm{HCl}$ 기반의 상품화된 탈회용액과 직접 제조 한 $\mathrm{EDTA}$ 탈회용액이 골수조직의 탈회과정에 어떤 영향을 미치는 지 분석하였다. 환자로부터 채취된 73예의 골수생검조직을 $\mathrm{HCl}$ 탈 회와 EDTA 탈회의 두 그룹으로 나누어 탈회과정을 진행하였다. 골 수생검조직의 탈회과정 후 결과의 차이는 hematoxylin \& eosin 
염색과 reticulum 염색, Ki-67, CD20, CD138의 항체를 이용한 면 역조직화학염색, DNA 추출 및 분석, in situ hybridization, IGH gene rearrangement 와 같은 분자병리검사를 시행하여 분석하였 다. 일반적인 염색과 특수염색에서는 두 탈회용액간의 차이는 없었 다. 또한 세포증식 표지자와 같은 세포막 혹은 세포질에서 발현되 는 항체는 탈회용액간의 차이 없이 잘 염색되었다. 반면 $\mathrm{HCl}$ 탈회 용액에 처리한 후 핵 내 단백질인 Ki-67의 염색상은 현저히 불량한 것으로 관찰되었다. $\mathrm{HCl}$ 탈회용액과 비교하여 $\mathrm{EDTA}$ 탈회용액에 서의 골수생검조직 내의 DNA와 RNA가 잘 보존되었음을 다양한 분자병리검사를 통해 확인할 수 있었다. 특히 $\mathrm{HCl}$ 탈회용액에 처리 한 28예와 EDTA 탈회용액에 처리한 12예의 DNA의 순도와 농도 을 비교한 결과 통계학적으로 유의한 수준으로 차이가 있음을 확인 하였다. 이로써 EDTA 탈회용액이 조직 내의 항원성을 잘 유지시키 며, 면역조직화학염색과 분자병리검사에 적합한 방법임을 확인 할 수 있었다.

\section{Acknowledgements: None}

Funding: None

Conflict of interest: None

\section{References}

1. Choi MS, Lee HS, Kwon HC, Bae MH, Ko YH, Kim HJ, et al. Optimal fixation and decalcification methods for bone marrow biopsy. Korean J Clin Lab Sci. 2015;47(4):243-250. http:// dx.doi.org/10.15324/kjcls.2015.47.4.243.

2. Sarsfield P, Wickham CL, Joyner MV, Ellard S, Jones DB, Wilkins BS. Formic acid decalcification of bone marrow trephines degrades DNA: alternative use of EDTA allows the amplification and sequencing of relatively long PCR products. Mol Pathol.
2000;53:336-337.

3. Dimenstein IB. Bone grossing techniques: helpful hints and procedures. Ann Diagn pathol. 2008;12:191-198.

4. Quintanilla-Martinez L, Tinguely M, Bonzheim I, Fend F. Bone marrow biopsy: processing and use of molecular techniques. Pathologe. 2012;33(6):481-489.

5. Choi SE, Hong SW, Yoon SO. Proposal of an appropriate decalcification method of bone marrow biopsy specimens in the era of expanding genetic molecular study. J Pathol Transl Med. 2015;49:236-242.

6. Erber WN, Asbahr HD, Phelps PN. In situ hybridization of immunoglobulin light chain Mrna on bone marrow trephines using biotinylated probes and the APPAAP. Pathology. 1993;25(1):63-67.

7. Alers JC, Krijtenburg PJ, Vissers KJ, Dekken HV. Effect of bone decalcification procedures on DNA in situ hybridization and comparative genomic hybridization: EDTA is highly preferable to a routinely used acid decalcifier. J Histochem Cytochem. 1999;47(5):703-709.

8. Singh VM, Salunga RC, Huang VJ, Tran Y, Erlander M, Plumlee $\mathrm{P}$, et al. Analysis of the effect of various decalcification agents on the quantity and quality of nucleic acid(DNA and RNA) recovered from bone biopsies. Ann Diagn Pathol. 2013; 17:322-326. http://dx.doi.org/10.1016/ j.anndiagpath.2013.02.001.

9. Sandberg Y, Van Gastel-Mol EJ, Verhaaf B, Lam KH, Van dongen JJM, Langerak AW. BIOMED-2 multiplex immunoglobulin/ T-cell receptor polymerase chain reaction protocols can reliably replace southern blot analysis in routine clonality diagnostics. J Mol Diag. 2005;7(4):495-503. http://dx.doi.org/10.1016/S1525-1578(10)60580-6.

10. Castania VA, Silveira JW, Issy AC, Pitol DL, Castania ML, Neto $\mathrm{AD}$, et al. Advantage of a combined method of decalcification compared to EDTA. Micro Res Tech. 2015;78:111-118. 10.1002/ jemt.22451.

11. Haiyan H, Weijun F, Hua J, Juan D, Lili Z, Chunyang Z, et al. The clinical characteristics and prognosis of IGH deletion in multiple myeloma. Leukemia Research. 2015;39:515-519. http:// dx.doi.org/10.1016/j.leukres.2015.02.010. 